\title{
The multiplicity of factors in the causality of railway accidents in Argentina: contributions to the debate
}

\begin{abstract}
In Argentina, researches and information about regarding the railway accidents are scarce. This work is intended to give elements for debate. As from secondary information regarding train accidents occurred in 2011 and 2012 in metropolitan railway lines, it is clearly shown that errors are not only made by first-line workers as the most traditional models of accidents analysis, but by the administration style and the managers who also carry huge responsibilities as from the point of view of management organization. In railway accidents, human errors are given a privileged place among other factors. The multiplicity of weak links of the metropolitan railway system promoted the succession of these accidents.
\end{abstract}

Keywords: railway transport, accidents, human error, safety management, risk management
Volume 4 Issue I - 2020

\author{
Natalia L Gonzalez \\ Instituto de Industria, Universidad Nacional de General \\ Sarmiento, Buenos Aires, Argentina
}

\author{
Correspondence: Natalia L Gonzalez, Professor Researcher \\ - Instituto de Industria - Universidad Nacional de General \\ Sarmiento - Buenos Aires Argentina, \\ Emailngonzale@campus.ungs.edu.ar
}

Received: November 17, 2019 | Published: January 20, 2020

\section{Introduction}

The "Once tragedy"1 was considered a turning point from the Argentinean railway policy perspective. This major accident and other accidents that occurred in the last few years in metropolitan railway lines, not only gave way to the debate concerning railway system security but the debate involving accidents' causes and responsible individuals. Therefore, human error centralizes incidents and accidents explanatory causes avoiding other relevant elements.

Two major accidents in metropolitan railway transport allow us to illustrate the importance given to this phenomenon. One of them occurred in February 2011, and the other one, in February 2012. The first one took place in San Martin railway line managed by "Unidad de Gestión Operativa Ferroviaria de Emergencia (UGOFE)" on a railway section shared with the company called "Ferrobaires S.A.". The second one took place in Sarmiento railway line- "Transportes Buenos Aires S.A. ( )"2. Later, it was considered one of the most serious accidents of the country. One of the accidents was caused by a train collision, and the other one by one train that did not stop and crashed its bumper at Once station. The main cause identified by many parties (for example, in the company, the communication media, etc) was human intervention: the distraction of the driver and the assistant or the lack of expertise are pointed as the causes of the accident (Source: Resolution made by Judge Yjal). Both accidents left lots of victims with a consequent impact on public opinion.

Therefore, our interest was focused on studying how human error is taken on railway accidents since, in Argentina, research and information regarding this problem are scarce even though the flexibility of statutory regulations, the conditions of the rolling and tractive stock, light signals, and brake systems are highlighted as intervening factors. All these elements are finally left aside due to the

\footnotetext{
'The "Once Tragedy" makes reference to a serious railway accident that occurred in a metropolitan line. More than 50 people died and hundreds suffered minor and sever injuries.

${ }^{2}$ After the accident, by Decree 793/12 published in the Official Bulletin on 24/05/2012, the national government cancelled the concession of Sarmiento and Mitre railway lines that was granted to "TBA", and gave it to a new management unit created by "Ferrovías" y "Metrovías".
}

importance given to the distraction, negligence and lack of expertise of railway workers.

Unicausality not only turns to be reductionist regarding the analysis of such phenomenon but also fosters errors repetition. Therefore, it is necessary to re-open the debate concerning human fallibility and the pattern used to analyze accidents.

Following the organizational perspective of the Normal Accidents Theory (Spanish: NAT) developed by Ch. Perrow, ${ }^{1,2}$ the High Reliability Organizations (HROs) theoretical developments, ${ }^{3-5}$ and the epidemiological and systemic model of J. Reason ${ }^{6}$ and E. Hollnagel, we wonder about factors and conditions that made these accidents possible including error as one the explanatory components. In this sense, Hollangel ${ }^{7}$ warns society about two new aspects as regards job safety, how inappropriate is to deal with safety disregarding business' point of view and the growing complexity of the study field. All in all, this work is about a thought that leads to debate opening, and that also helps overcoming the reductionist character of conceptual frameworks, and the understanding of the part played by organizational factors. From secondary and theorical sources, it is raised the debate about human error as from two serious accidents occurred in the metropolitan railway lines. ${ }^{8}$

\section{About the evolution of accidents analysis' theory}

The conceptual frame of the analysis of accidents has evolved from the "domino theory" to more complex perspectives that presume confluence of factors. Industrial Accident Prevention, ${ }^{9}$ is considered a classical work on workplace safety which identifies five sequential factors of an accident: 1) background and social environment; 2) worker's failure; 3 ) unsafe acts bonded to mechanical and physical risks, 4) accident, 5) damage or injury. The key one according to the author is number three. Therefore, if it is possible to eliminate the fact related to unsafe actions, it will be possible to decrease consequences and/or even accidents.

Along with this list of factors, Heinrich pyramid is another tool of great success as regards accidents analysis. It supposes that, on the 
face of an accident that causes a major injury, (for example, death) (it is placed on the top vertex of the pyramid) other 29 accidents causing minor injuries and 300 incidents with no consequences take place. The pyramid achieved a great impact and acceptance among accident prevention scholars since it conjectures that, if near miss reports are studied thoroughly, it is possible to avoid or interfere with more severe accidents. Consequently, it has been given continuity to this tool by incorporating steps in the pyramid, and making a distinction between accidents implying working days lost, or not, in subsequent studies. ${ }^{10,11}$

Nevertheless, the perspective and Heinrich pyramid have been strongly questioned not only by the sequentially regarding accident explanation, but also due to the scarce or null empirical data used to get to the proposed ratio.

The analysis of the accidents may have three stages since they are taken as a sequential model: the first one has found and considered the explanatory causes of the accidents in technological, mechanical or equipment factors. The second moment is the one that nourishes from unsafe actions developed by individuals when performing a task. The third one, is the one where socio-technical or organizational factors ${ }^{6}$ are given much importance. Sequential models describe accidents as the result of a group of factors or events that occur in a certain order. This is a cause and effect concatenation (for instance, the domino model, root cause).

Errors are referred as one of the most important factors regarding accident achievement. They have been thoroughly studied in order to try to explain disturbances and accidents. "Reason" points out that errors and intentions are inseparable. Therefore, it is possible to make two kinds of errors: the first one, on which the achieved result is much different from the original intention, and the second one, on which the modified actions correspond to the process and are different from our intention. In this sense, both basic ways of errors are: the one that implies a failure in planning, as the first example, and which is about making errors, and the way that implies execution failure which is called slip or lapsus. Therefore, "Reason" takes over the classification of the origin of basic human errors described by Rasmussen, ${ }^{12}$ and points outs that the slips or lapses are based on abilities, and that errors may be divided in those errors based on rules, and those ones based on knowledge.

Even though there has been certain evolution in identifying the causes of the accidents, their sequential or causality principle of the accidents is still present in the most contemporary models. The analysis starts from the cause and effect relationship that arises between the factors implying occurrence and responsibility and, therefore, consequent measures in a unique causative factor.

Decentralizing from a unique factor implies thinking about accidents as causing networks, factors interaction and multiplicity, and a chain of consequences. Surpassing consequential models, a second group describes accidents as from the analogy between medicine and sickness. The epidemiological model ${ }^{13}$ helps realizing a factors' combination (for example, latent, evident) that co-exist and entail accidents. It differs from the sequential model in four relevant aspects: the idea of human error is replaced by acting deviation; environmental conditions (i.e., not only labor conditions), the installation of barriers that may avoid unplanned consequences (for instance walls, harnesses, fences, filters), functional consequences - passwords, airbags, distance-, symbolic consequences -instructions, signals, working orders-, incorporeal consequences -self-control, moral, laws, and latent conditions (i.e. they are within the system much before than the starting point of a recognizable accident sequence).?

The most famous tool of this perspective is the "Swiss cheese" model..$^{13}$ Its core point is the concomitance of failure apart from human and system errors. It asserts that all systems have security barriers that may turn out to be porous, with "holes"- that is the reason why the cheese metaphor is mentioned- and the accidental situation happens when the holes of many barriers match. When this coincidence occurs, there may appear active failures that are made by individuals who are in direct contact with the system (operators basically), and latent conditions that are inner problems of the system which are hidden. In this sense, the epidemiological model has been an evolution of the accident's analysis since it allows overcoming the restrictions of sequentiality, and also opening a discussion about the interaction of factors involved in an accident. However, accidents try to be avoided or corrected setting apart all factors that promote the deviation of actions.

The third model group happens at the same time that sociotechnical factors are given more importance as from the analysis of the "Three Mille Island" 3 accident. The systemic model considers accidents as an emergent phenomenon, and tries to describe the characteristic performance of the system as a whole. ${ }^{7}$ It nourishes from the theory of systems and cybernetics, and looks into getting to know the components of the systems, interrelationships and its units, and the variability potential supposing that the variability of any function is affected by the variability of the rest of the system. This approach to accidents implies a sequence of facts, but each of them may be preceded by a group of events. Therefore, each of the facts may be followed by many events.

Two key elements of the systematic model are the execution and design area. The first one describes the place where people are executing duties at the time of the accident, and the design one identifies their working boundaries and resources. Consequently, the accident cannot be described neither as a causal chain nor as a causal net since, therefore, interactions are not taken into account. Systems have a variability that, a priori, cannot be taken itself as harmful or favorable, but it must be identified and analyzed. The model involves certain steps as regards analysis of accidents. The first one, refers to the identification of the core functions of the system. Therefore, the systems and its components shall be identified. Secondly, it shall be determined the potential of the context variability and of the main (i.e., human, technological and organizational) functions, and lastly, countermeasures shall be decided (for example, policies, defenses, monitoring, proceedings, communication, etc.).

Finally, Hollnagel ${ }^{7}$ highlights that it is wise to take into account the model analysis of accidents because methods not only have an impact on the understanding of the event, but also on how resilience is understood. In that sense, the resilience of a system might be affected by an abrupt event, or by incidental little events that slowly erode safety boundaries.

${ }^{3}$ The Three Mile Island (TMI -) accident happened on March 28th, 1979. It was a serious nuclear accident with partial fusion of the core of reactor number 2 of Harrisburg central (United States). It was rated as level 5 in the International Nuclear and Radiological Event Scale (INES). Before the Fukushima accident that took place in Japan, it was considered the most serious accident of the history of nuclear industry. 


\section{The systemic model in organizational theory}

Along with the systemic model, from the Normal Accident Theory (NAT) to the Theory of High Reliability Organizations, ${ }^{4}$ the studies of accidents ${ }^{3,14}$ have been monopolized considering organizational theory.

The theory developed by Charles Perrow coincides with the systemic model regarding the variability of the performance since, according to ontological characteristics, risky organizations inevitably lead to ordinary accidents. These systems have two main characteristics: the interactive complexity, which relates to the way the failures of components interact, and secondly, the strong ${ }^{5}$ interaction that implies the speed of the processes that are mutually dependent. Integration means that there is not laxity or flexibility between two elements. The point is that what happens to an element affects the other one. ${ }^{14}$ Complexity is analyzed through a series of dimensions such as the space provision of the equipment, the manufacturing lines, and the steps of a productive process and its proximity, the shared connections, the interconnected subsystems, the multiple control systems, the expertise of the employers, the unexpected or unknown feedback loops, the level of materials' replacement and the processes understanding. On the other hand, integration contemplates the variability of productive sequences, the redundancy devices, equifinality, flexibility and substitution ability of the supplies, the equipment and the employers. These dimensions may be used to describe the events of the execution, design and planning field proposed by the systemic factors.

\section{The study of accidents in the railway system}

The railway system is usually barely used as a subject matter. Former studies refer to big accidents and those focused on the vulnerability of the system. There is a prevalence of technical or engineering studies or studies regarding human beings, the responsibility and the individual blame. The empirical studies that are focused on this issue make reference to human error as an unavoidable axis of the vulnerability of the railway system trying to explain accidents and incidents and safety implication. ${ }^{15-24}$ Other groups of study make a warning about repercussions or the impact of working conditions and working environment of employees. ${ }^{25-28}$

History and economy are disciplines that have mostly studied the railway system in Argentina. Both have been studied as from the follow-up of the railway policy, the railway origins, and the process to obtain a concession of railway lines. Some technical works deal with the railway management, the improvement of the reprogramming processes of trains, the conditions of working risks and the progress on regulations regarding railway accidents, the technological system and the railways in Latin America. ${ }^{29-36}$

In Argentina, the consequences after the accidents as post-traumatic stress, sleeping disorders and psychosocial problems are also part of the corpus in an incipient way in Argentina. However, human factor takes a privileged role in the analysis of accidents for being the root cause of the errors that explain the succession of catastrophic events.

In nuclear industry, after the analysis of the Three Mile Island (TMI) accident, people started realizing other very relevant points regarding the study of incidental or accidental events. Apart from the human factor, $\mathrm{Law}^{37}$ describes other elements of the Ladbroke Grove railway accident as the atmospheric effects, organizational culture and management failure. ${ }^{38,39}$
Two main causes of big railway catastrophes are mentioned in the studies carried out in Great Britain: train crashes and crashes between trains and vehicles. A research from the Department of Civil and Environmental Engineering of Imperial College London ${ }^{40}$ mentions the following situations as the general causative sources of accidents in Europe: ignoring warning signs, overspeed, errors on signals or errors of "train dispatchers", failure on the rolling stock or on the infrastructure or rail points, other operational errors, external factors of trains and railways. Even though the accidents rates in Europe have been considerably reduced lastly, the reduction is not registered under a certain type of accident. Tendency shows that the main root of accidents is the fact of ignoring warning signs, followed by errors on signs or errors from train operators.

On the other hand, Reinach y Viale, ${ }^{22}$ developed a taxonomy composed by five groups that cause accidents. They are divided in: operators' actions, previous conditions regarding operators' actions, supervision or control factors, organizational and external factors.

Consequently, apart from human mistake which has been analyzed many times as from the dominant safety paradigm, there are other possible vulnerability sources associated with rational action such as breaking regulations, pitfalls, transgressions and lies, outbursts or regulations. ${ }^{8,41-44} \mathrm{~A}$ few studies describe the contribution of workers as regards regulations redrafting and the shared knowledge in the railway system. ${ }^{46,47}$ As from the ergonomic point of view, there are some studies about shared situational and cognitional knowledge socially distributed in the railway transport area.

Roth et al. ${ }^{48}$ develops the theory of how team practices and shared situational knowledge may contribute to the overwhelming resilience system of human errors and, in parallel, forecasting events, thus increasing safety levels regarding transactions and organizations as a whole. The shared situational knowledge allows the performance of practice emergencies or cooperative strategies which lead to reliability. Behind these informal practices, it prevails a spontaneous and proactive type of communication.

De la Garza y Weill-Fassina ${ }^{47}$ point out the need of the workers to redraft the regulations prescribed by the organization in order to balance the disturbances of the working process. Therefore, the authors analyze collective work in two specific working situations at railways: maintenance activities and work execution, and rails repair in order to understand regulation mechanisms and compensation in labor situations. In parallel, De la Garza and Weill-Fassina ${ }^{47}$ highlight four types of interactions: co-activity which implies that two different specializations work together in a common geographical space; co-action which refers to different actions that, in a long term, get together in a unique activity though originally correspond to different objectives; cooperation which is the main characteristic of those operators who work together to fulfill the same objective, and collaboration which implies that operators execute different actions on the same objective.

De la Garza ${ }^{46}$ developed the pivot points method for the railway area. Pivot points refer to elements that cause perturbation or change of state of a system that cannot be balanced since operators do not respond properly because the they do not have the means or the enough time to do it. In this sense, incidents analysis and pivot points, taking into account that they imply a process that results from unplanned interactions in task development, allow the identification of organizational failures, design and latent errors (Table 1). 
Table I Data on railway accidents

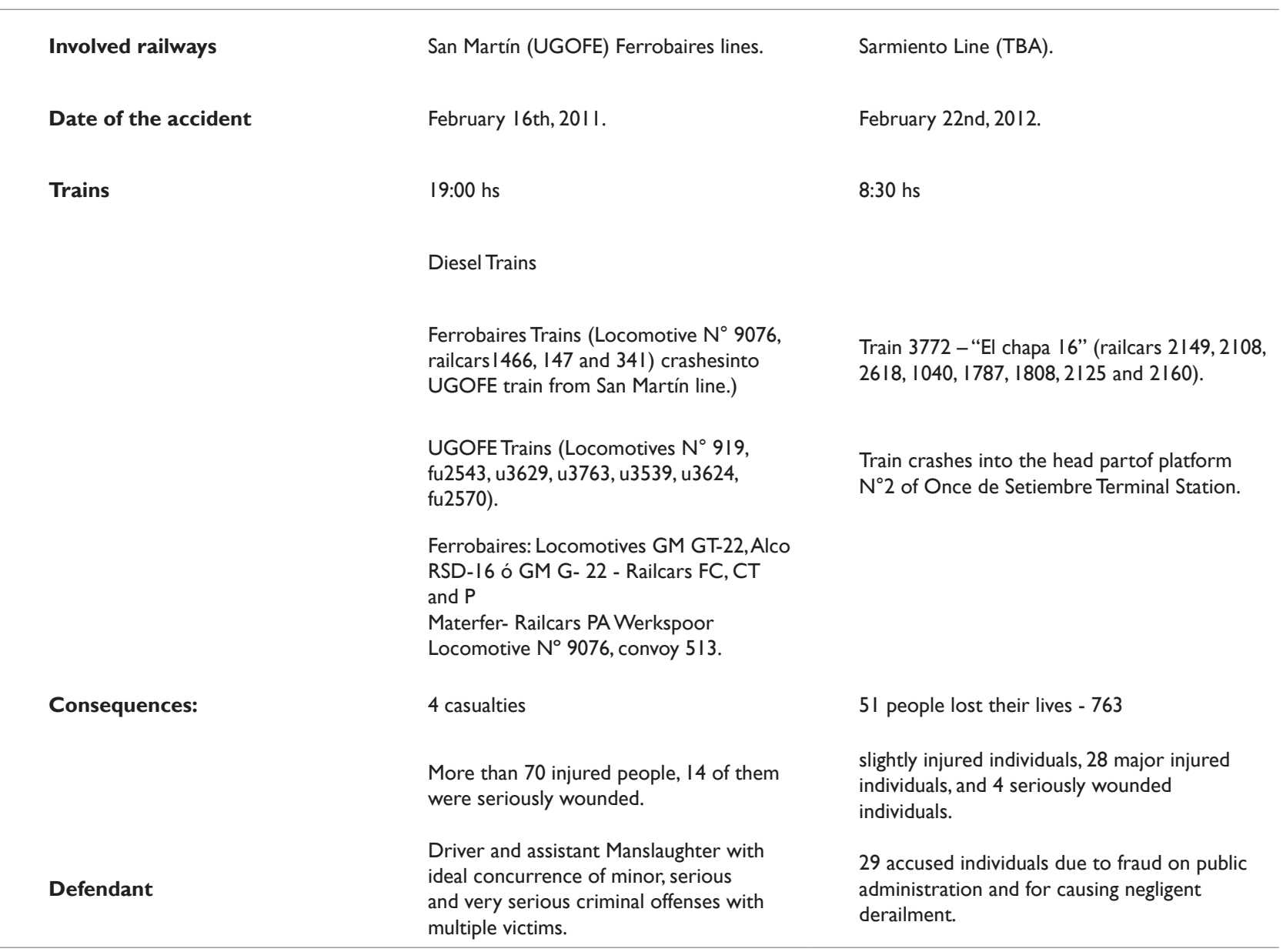

Source: self-studies pursuant Case 17/0/12 and Case 5695/II

Thus, even though human factor keeps the first place as regards accidents' analysis, a lot of events associated to other technical, social and organizational aspects emerge. ${ }^{37}$

\section{The human error in railway accidents}

In the railway system as well as in other systems, the mail accident source is human error. In other words, railway drivers, signalers or employees' errors. ${ }^{21}$ In addition to that, there are other accidents due to rail obstructions, defective rails, and problems with rolling stock. As regards types of drivers' errors, it is mentioned the SPAD one (signal passed at danger) which implies trespassing a sign that warns operators about a future event if they continue driving. Excessive speed at crosses or during the journey, as well as brake problems, are part of the errors attributed to drivers.

Over the last few years, many major accidents on the railway metropolitan passenger lines brought out, one more time, the debate as regards safety and sustainability of railway transport.

In May of this year, ${ }^{6}$ the driver of train that that caused the accident in Castelar city on June $2013^{7}$ was sentenced to four (4) years and three

6udgement of case FSM 46005059/20 I3/tol-27/05/20I5.

${ }^{7} \mathrm{~A}$ railcar crashed the back of another stopped railcar that was between Morón and Castelar (Buenos Aires). Due to this accident, three people died and there were dozens of injured people.
(3) months of jail; he also received a special prohibition to drive any kind of train for ten (10) years. In the judgement, the defense attorney highlights that, after the accident, political authorities wanted to expose that the tragedy that occurred in Castelar, was the consequence of human failure. In that sense, the defense attorney points out that the photographs of the dashboard panels of the train were made public, the court case videos were shown on communication media and conclusions of the expertise reports were published. Consequently, it was created a collective consciousness about the perfect conditions of the train and, that the accident was caused due to human failure. The document also points out some statements that make reference to a number of practices that differ from regulations such as "constant order of signs transposition", "malfunction of signs that caused routinization", and that otherwise, "trains wouldn't run". This topic has been deeply studied by Vaughan ${ }^{45}$ who highlights that breaking regulations or making a deviation from them is a frequent fact, and that even this could be taken as a routine and lead to catastrophes. Both the Challenger and the Columbia case represent the empiric evidence provided by the author in order to identify the normalization of deviation. However, as from the work sociology and from the sociology of organizations, "informal overflow" or "regulations" are being studied every time regulations are not enough to manage work process, and uses informal organization to give an end to the activity. 
The LAPA ${ }^{8}$ case is an interesting precedent that shows what happens with analysis of accidents in complex systems (e.g. either on a railway line or on an airline). The (JIICA, 2000; CFCP reg. $\mathrm{N}^{\circ} 46.2014 .4$, 2014) report points out that the accident is produced because the pilots forgot to flap down. The pilot and co-pilot died in the accident so, as different from railway accidents, they could not be accused. However, they may bear responsibility for the catastrophic event. The report thoroughly focuses on the personal and professional characteristics, as well as on the personal difficulties of both individuals pointing out the usual lack of discipline during flights. In reference to this matter, it is important to include Amalberti's perspective ${ }^{49}$ who describes high risk systems as from the actions of the individuals at work. The author considers that error mechanisms have been given excessive importance in order to explain the failures of the operator, and that it really explains much less than it seems. Therefore, he proposes a cognitive model that allows the understanding of intelligence and fragility of cognitive commitments of the operators in ordinary work situations and work dynamics to guarantee safety and performance. $\mathrm{He}$ also proposed analyzing the breaking causes of commitment as regards high technological systems of LAPA case. In parallel, the aim of this model is not to inquire about the breakup of cognitive commitment in LAPA case; the managers of this organization are not considered responsible parts. LAPA Director and the general manager were acquitted of the case even though they were charged for not complying with the appropriate activities and duties (e.g. conditions of the planes, lack of professional authorized licenses or expired licenses of the pilots, fulfilled amount of flight hours of the pilots, lack of training, manuals that do not accomplish aircraft industry requirements) ${ }^{9}$ and, consequently, determining the cause of the accident. Finally, the co-responsible parties were the Flight Line Chief and the Flight Line Operations Manager who were sentenced.

\section{Two railway accidents in metropolitan lines}

Pursuant to State Reform Law $\mathrm{N}^{\circ} 23.696$, all railway lines were granted in concession. As regards metropolitan railways, they were granted in concession achieving a triple alliance of essential individuals composed by local economic groups, foreign and local banks and/or transnational corporations. ${ }^{31}$ Once granted in concession, even though the first years the companies managed to recover a percentage of passengers and to improve the services frequencies, after the crisis in 2001, it was passed the Railway Emergency Law which cut off all works, jobs and planned works provision. This Law also eased the predefined sanction system for concession holders. At that time, it also ceased the rate of services accomplishment so the rails maintenance, the rolling stock and the railway infrastructure as whole were suspended as from the enforcement of this law. The two accidents chosen for illustrating this topic correspond to two metropolitan lines under concession (i.e. San Martin and Sarmiento lines). The concession of the first one was discontinued after recurrent non-fulfillments from the company. ${ }^{50}$

The accident in San Martin line: on February $16^{\text {th }}, 2011$ at about 19:00 hours a railcar from "Ferrobaires" departed from "Retiro" station of the Autonomous City of Buenos Aires. The final destination was Junín city, Buenos Aires Province. The train crashed into the back part of the local train of General San Martin line between "San Miguel"

${ }^{8}$ On August 3 Ist, 1999 the Boeing $737204 \mathrm{C}$ corresponding to flight 3142 of LAPA airline crashed into Jorge Newbery Airport.

${ }^{9}$ Enrique Piñeyro, a former LAPA Captain had reported safety LAPA aircraft problems, such as the lack of maintenance and reparations, or mechanics who disregarded the reparation requests from the pilots, among others and "José C. Paz" railway stations. The 3443-local train of passengers of San Martin line managed by UGOFE ${ }^{10}$ headed Retiro station from José C. Paz. On the other hand, Ferrobaires' train departed from Retiro station at 18:15hs to Junín. Ferrobaires crashed into the back part of the former one. The ( $\mathrm{N}^{\circ}$ 9076) locomotive crashed into the last goods wagon of the train that belonged to the "General San Martin" line. The accident lead to two fatalities and many wounded people. The next day, once photographs and primary expertise activities were carried out, it was made an ocular inspection of the signaling system.

Ferrobaires 'locomotive was running with the driving wagon at the end of all wagons [Spanish: "trompa larga"] ${ }^{11}$ and it could be proved that the brake system was not activated. It was set with free brake system. The electric circuit was cancelled. The dead man's pedal was disconnected and it was nailed to the floor. The emergency brake was locked with a padlock and wire. From the mechanical inspection it was found out that the headed north boggie ${ }^{12}$ and the headed south boggie had no break setting. As regards railcars, it is identified that in 1466 and 147, the north headed boggies had brakes deactivated, and headed south ones did have them activated. In 341, both boggies had no brakes. This could have happened due to the time gap from the collision to the inspection. (Source: Case 5695/11).

The accident in Sarmiento line: railcar $\mathrm{N}^{\circ} 3772$ was running through the descendent line from Moreno to Once de Septiembre station. It got there at 8:28:23hs. The train crashed into the platform header. The train was running without one of its compressors. The other compressor was out of order. The recovery time of the brake system pressure was higher as regards manufacturer's specifications. The maintenance of most of the railcars had been deferred. The safety device of the dead $\operatorname{man}^{13}$ was deactivated. During the trip, the motorman reached $72 \mathrm{~km} / \mathrm{h}$ in 2.500 meters. Before the crash, the GPS showed that the train was running at $20 \mathrm{~km} /$ hour. The train had been running approximately 300 meters at the same speed. (Source: Case 1710/12).

\section{The multiplicity of factors in the causality of railway accidents}

The systemic model ${ }^{9}$ supposes a series of steps regarding the analysis of an accident. The first one makes reference to the essential functions of the system. Therefore, the system and its components need to be determined. In this sense, it is important to know the railway system. Secondly, the potential of the context variability and the potential of the main functions (i.e. human, technological and organizational functions) have to be determined; the third step refers to the (i.e. correct and incorrect) function's dependability, and lastly, countermeasures have to be decided (e.g. political, monitoring, proceeding, communication ones).

\footnotetext{
${ }^{10}$ Unidad de Gestión Operativa Ferroviaria de Emergencia (UGOFE) was composed by three railway service concessionaries: Ferrovías, Metrovías and Trenes de Buenos Aires (TBA).

"It refers to the location of the locomotive since the driving cabin allows the two-side driving way. When it has the "trompa larga", the cabin remains at the end, and the motor of the locomotive remains at the end of it.

12boggie is a spinning device that has two or more axis. Each of one has two wheels that support a railway vehicle.

${ }^{13}$ The dead man device and its nulling show the lack of accomplishment of the regulations in order to improve labor conditions. Currently, new "Live Man" [HV] systems have been incorporated. They detect the actions of the individual that show the human control within the driving cabin in a systematic and continuous way. Conceptually, a static and fixed action is replaced by a dynamic action of the system reset, usually in a cyclic and repetitive way. (Cfrt. Technical Bulletin No MR-I-2013).
} 
Following the theory of ordinary accidents, the railway corresponds to a system of lineal interactions and it has a high-integration level. However, the fundamentals of the author lack of theoretical grounds and, specially, they lack of empiric evidence. Therefore, railway accidents firsty refer to the nature of the Argentinean railway system. In this sense, we consider that the Argentinean railway system refers to a complex interaction and to simple integration. ${ }^{52,53}$ It is refuted the intuitive idea of $\mathrm{Ch}$. Perrow on the grounds of, not only technological variables, but also on organizational and contextual aspects.

The underlying message of the systemic model is that, the way of expressing the system and the accident, have consequences regarding the way that results or consequences are faced. It is focused on how conditions that lead to accidents may start.

As regards factors multiplicity and their variability concerning the case held in San Martin (Ferrobaires), a confluence of (i.e. human, technological and organizational) dimensions may be mentioned. The technological factors show the lacking of basic spare parts of the rails and the work itself, as well as the worrying failures from the safety point of view. However, in the first place, the prosecuted parties were the driver and the assistant. After analyzing the accident, the inspector of ${ }^{14}$ issued a report for the provincial Legislature pointing out that only the $15 \%$ of the locomotives ( 12 over 81 ) and only the $17 \%$ of the railcars ( 84 over 507$)$ were only working by mid-2011.

At the time of the accident, the electric circuit of the locomotive was disconnected and the emergency brake was sealed. The whole train had many irregularities from the mechanical point of view. Therefore, the driver makes the following statements which is included in the file of the case: "If they tell me that I can run the train this way, I do it. I mean, that if the different departments of the corporation approve the running of the locomotive and the railcars, I must not refuse to do it." (Case 5695/11: p.14). Also, the driver's assistant states: "the train departed due to labor and social pressure because if we refused to render the services, it would have the same society the one that would have blamed us for the lack of action and, though the union supports us, the company would also would have punished us by denigrating our working conditions."(Case 5695/11: p. 18).

After the reconstruction of the accident, the judge stated before the media the confirmation of the serious negligent hypothesis highlighting human mistake as the cause of the incident. It is therefore concluded that the defendants (i.e. driver and assistant) did not met the safety goal regarding safety since they were not able to keep the danger that derived from a risk activity under complete control, even though the means of protection of the system were working properly and, the driver and the assistant, had the abilities to make them run properly. Consequently, human error is again mentioned as the root cause of the accident. The fiscal of the case requested the questioning not only of the driver and the assistant, but also of the employees of tractive mechanics, rolling and maintenance area, who are the ones in charge of the revision of the locomotives and railcars.

As regards human factor, it is described that either the driver and the assistant, have wide-ranging experience concerning driving locomotives, and that they have acquired 15 and 10 years of seniority respectively. Moreover, the file of the case states that they were not drunk and that they were in good health. As regards organizational

\footnotetext{
${ }^{14} \mathrm{After}$ the accident, the provincial government intervened the "Unidad Ejecutora del Programa Ferroviario Provincial" for 180 days through Decree II9/II.
}

management, after the report submitted by the inspector, all senior leadership of Ferrobaires was renewed.

As regards the accident of Sarmiento line (TBA S.A.) it can be pointed out again a multiplicity of factors which were extremely connected, and that could be the root of the accident. However, in comparison to the previous accident, this one shows details that put it in a serious organizational negligent situation even though, firstly, human mistake is also identified as one the main causes of the accident.

The reports of the National Transport Regulatory Commission [Comisión Nacional de Regulación del Transporte (CNRT)] and of the National General Audit Office [Auditoria General de la Nación (AGN)] are determining. The $50 \%$ of the line derailments reported in 2008 , and the $61 \%$ of the ones reported in 2009 occurred due to differences between the rolling stock and the infrastructure of the rails. Moreover, the same years, the sources of the mentioned accidents were the infrastructure of the rail-between $17 \%$ and $29 \%$-, the rolling stock -between $33 \%$ and $64 \%$, and human errors - between $7 \%$ and 50\%- (AGN 303/09, year 2012: 85-86).

Specifically, at the time of the accident the train was overloaded, the brakes did not work properly, the train was running without the compressor, and the dead man device was deactivated. Moreover, it was also found out that the repairing of the damaged railcars was carried out through confusing methods of indirect costs.

In reference to human factor, the driver had a two-years' experience as driver of electric trains. Before that, he worked as a driver of diesel locomotives, which means that he had been working for T.B.A. S.A. for five years. The driver was in good health; he did not suffer from epilepsy, and he was not drunk at the time of the accident. He was 26 years old. An additional element, that it is possible to analyze again, refers to the labor career of the drivers. ${ }^{15}$ The individual enters the company and gets promoted through different categories until achieving the drivers' position. The training to get to that position is held at the é ó ${ }^{16}$ [Technical Driving School], which works under the management of La Fraternidad, and where the individuals are tested with the presence of CNRT when finishing the course. Therefore, time schedules and diagrams definitions are made by the workers themselves. As a consequence, it may occur that the complex time schedules are assigned to younger and less experienced drivers. In short, a twenty-six-year-old young man with little expertise is responsible for the safety and the lives of more than 2500 people.

The school started in 1890, at the time "Academia de Instrucción para aspirantes a maquinistas de locomotives ferroviarias" was founded. That educational department is still working. Until the ' $90 \mathrm{~s}$, schools provided courses, and the candidates and drivers' assistants attended them, without rendering the service. Under the management of private concessions, this situation changed completely since individuals had to combine the rendering of the services with the courses during non-working hours.

As regards organizational management, the indictment of the accident held in Once describes the declarations of many of the TBA members who were not aware of the serious problems that the railway line had at that time and, in parallel, the relationship between their

\footnotetext{
${ }^{15}$ Originally, the course could only be attended by family members, giving priority to the sons of the drivers. Currently, same as before, the individual starts as "candidate", i.e. candidate to driver's position.
} 
role, safety and the management of the line. To carry out the railway transport of passengers, contracts and rendering of services were executed; this caused financial damage to public goods and funds of the National State. A number of expenses that were not related to the rendering of services were identified: private flights of directors, huge expenses of people who were not employers of the company (e.g. Winery, La Orquidea Shop, jewelry, furniture bought in the French Polynesia, bags, sponsor of a race car, travels by plane, and hotels stays in Spain, Mexico, Colombia, Italy, France, Chile, Perú).

On the file it is stated that the managers behaved in a delinquent way and that they have taken many illegal and illicit decisions or that they participated in taking those decisions being aware that their accomplishment would strongly affect the infrastructure maintenance programs, the rolling stock and the training of the skilled employees. (Case 1710/12: p. 25).

In this context, after freezing the fees of public services which derived in lack of financing caused by costs and salary increases and inflation, the national government launched a subsidies programs for operative and current expenses. One of the bases that TBA uses to justify the delay of preventive maintenance is the delay on the subsides transfer.

An interesting point of the analysis of systemic model is on the point of Deciding the Countermeasures: specifically refers to defining where the barriers need to be settled. From this point of view, the Argentinean railway system had lots of possible areas to be improved without making an exhaustive analysis - rails and works infrastructure, rolling stock and working conditions at first sight.

Unfortunately, as part of railway policy, many measures were started to be considered after the Once tragedy. Lots of measures were carried out starting from precise operative measures to long term investments ones. As regards operative point of view, it is possible to mention a "live man" device which works by detecting actions which systematically and continuously shows human control within driving cabin, regulations regarding compatibility, and safety conditions that locomotives must comply with. New safety regulations for train drivers (e.g. medical checkups, new communications protocols), additional trainings were also implemented. There are some other measures that are related to a longer-term railway policy such as the enactment of Law 27132 concerning Argentinean Railways, the process of renewal of the rolling stock, the trains monitoring centers, the communication system, and the installation of on-board and rail equipment. Contract with Chinese corporations were settled for the provision of rolling stock. Both Chinese companies are interested in settling in Argentina in order to manufacture spare parts and locomotives for Argentina and Brazil.

These measures come together with certain restrictions such as lack of development of a local industry, the dependency of Chinese corporations for training and learning how to use rolling stock as well as machinery and spare parts. There are delays concerning works executions, about twenty contracts were suspended (e.g. rails renewal, recovery of rolling stock, signaling) because they were not executed as stated by public works law and a re-determination of prices was not carried out.

\section{Conclusion}

The multiplicity of weak links of the metropolitan railway system enable the occurrence of these accidents though the causality is centered on the human error of the first line workers (i.e. driver and assistant).

Human reliability is well known, but the outstanding point is that errors are not the only causes of the accidents such as it is highlighted by the most traditional models of the accidents' analysis. The administration style, the managers, and organizational specifications take a substantial part of the responsibility.

The chain is no stronger than its weakest link. The accident that happened between two railway lines, Ferrobaires and UGOFE, tells that, even though, the explanation of human actions is being privileged, lots of errors, maintenance deficiency, and technical problems of the locomotive that crashed into the train at standstill were proved. The case was re named as voluntary manslaughter considering that the drivers made a serious mistake. Taking into account the execution, design and planning areas that the model of the systemic analysis of accidents suggests, it allows the visualization of other factors such as organizational and contextual ones. In another accident that happened on April of the same year and which was caused by Ferrobaires, the judge considered that, even though the company had many deficiencies, the conditions of the locomotives and the railway infrastructure were dubious, the accident was the result of the reckless actions of the drivers.

A multiplicity of critical factors must inevitably be taken into account when starting analyzing an accident; they arise through more systemically complex models. Although a priori it was determined that the train of the Once Tragedy ran almost 300 meters without speeding or breaking and finally crashed into the hydraulic bumper (which was not working) at the station, it was possible to identify management responsibilities, managers, and, as regards public role, the direct functional implication concerning the running of the railway.

Many accidents' researches identify human causes and, even though they are not decisive, decisions are taken on those grounds such as it is highlighted in the judgement of the accident that happened in Castelar and, in the indictment sheets of the Ferrobaires-UGOFE, the accident that still has no judgement.

The "Once Tragedy" occurred in 2012 marked a tipping point in many senses. Not only the responsible parties from different areas (i.e. "Trenes de Buenos Aires" managers- Sarmiento line) and public officers who had to control the direct functioning of the railway line were identified, but also maintenance and driving operations. Work management also emerges as a relevant point since a young man with no expertise at all was the responsible driver of a locomotive.

Moreover, the case turns out to be paradigmatic because it was not only about a railway accident, but about the actions taken by a group of people that behaved in a delinquent way and that affected the performance of the rolling material, the railway infrastructure and the training of the employees through the misuse of public funds.

Finally, the case impacted on the railway policy. From that moment on, a transformation process of the system was started. Its main axes were the recovery of the public management of the system, and the planning of the technological and infrastructural update. These axes turn to be an advantage if we combine the analysis of the unwanted events with conceptual frames that end up with the exclusivity of human error. Even though human beings tend to make errors, they are also able to make great contributions. In previous works ${ }^{54-56}$ it has been identified a series of practices developed by drivers and drivers' 
assistants who make a specific action system capable of forecasting and contributing positively regarding disturbances' management of the Argentinean railway systems.

Apart from that, the Argentinean railway, in general, and the metropolitan railway, in particular, still keep lots of unfinished business concerning support, development and safety matters.

\section{Acknowledgments}

None.

\section{Conflicts of interest}

The authors declare no conflict of interest.

\section{Funding}

None.

\section{References}

1. Perrow CH. Normal Accidents: living with high-risk technologies. New Jersey: Princeton University Press; 1984, 1999.

2. Perrow $\mathrm{CH}$. The next catastrophe. Reducing our vulnerabilities to natural, industrial, and terrorist disasters. New Jersey: Princeton University Press; 2007.

3. La Porte T. "Fiabilité et légitimité soutenable" en BOURRIER M. (dir.) Organiser la fiabilité, París: L'Hartmattan. 2001.

4. La Porte T, Consolini P. Working in practice but not in theory: theoretical challenges of "High-reliability organizations". Journal of Public Administration Reasearch and Theory. 1991;1(1):19-48.

5. La Porte T. High reliability organizations: unlikely, demanding and at risk. Journal of contingencies and crisis management. 1996;4(2):6071.

6. Reason J. El error humano. Madrid: Editorial Modus Laborandis. 2009.

7. Hollangel E. Barreras y prevención de accidentes. Madrid: Modus Laborandis. 2009.

8. Reynaud J. Les regles fu jeu: L'action collective et la regulation sociale. Paris: Armand Colin Editeur. 1989.

9. Heinrich W. Industrial accident prevention: A scientific approach. New York: McGraw-Hill; 1959.

10. Bird F, Germain G. Practical loss control leadership. Loganville GA: Det Norske Veritas; 1996.

11. Rebbit D. El poder de las pirámides. Professional Safety, 2014.

12. Rassmussen J. Skills, rules, and knowledge; signals, signs, and symbols, and other distinctions in human performance models. IEEE Transactions on Systems, Man, and Cybernetics. 1983;13(3):324.

13. Reason J. L'erreur humaine. Paris : Presses Universitaires de France, Collection Le Travail Humain. 1990.

14. Perrow $\mathrm{CH}$. The limits of safety: the enhancement of a theory of accidents. Journal of contingencies and crisis management. 1994;2(4):212-220.

15. Dhillon B. Human realiability and error in transportation systems. London: Springer-Verlag London. 2007.

16. Perpinya X. Reliability and safety in railway. Croacia: In Tech; 2012.

17. Catino M. A review of literature: individual blame vs. organizational function logis in accident analysis. Journal of Contingencies and Crisis Management. 2008;16(1):53-62.

18. Weick K. Organizational culture as a source of high reliability. California Management Review, winter, 1987; XXIX(2):112-127.

19. Weick K, Roberts K. Collective mind in organizations: heedful interrelating on flight decks. Administrative Sciencie Quarterly. 1993;38:357-381.

20. Rochlin G. How to hunt a very reliable organization. Journal of contingencies and crisis management. 2011;19(1):14-20.

21. Andersen T. Human Reliability and railway safety. 16 th European Safety, Reliability y Data Association (ESReDA), Seminar Safety and Reliability in Transport. 1999.

22. Reinach S, Viale A. Application of human error. Framework to conduct traian accident/incident investigations. Accident Analysis and Prevention. 2006;38(2006):396-406.

23. Sharit J. A modeling framework for exposing risks in complex systems. Risk analysis. 2000;20(4):469-482.

24. Baysari M. Caponecchiaa C, Abdrew S, et al. Classification of errors contributing to rail incidents and accidents: a comparison of two human error identification techniques. Safety Science. 2008;47(2009):948-957.

25. Krause N, Rugulies R, Ragland DR, et al. Phsysical workload, ergonomic problems, and incidence of low back injury: a 7.5 years prospective study of San Francisco transit operators. Am J Ind Med. 2004;46(6):570-585.

26. Evans AW. Fatal train accidents on Europe's railways: 1980-2009. Accident Analysis and Prevention 2011;43(1):391-401.

27. Baysari MT, McIntosh AS, Wilson JR. Understanding the human factors contribution to railway accidents and incidents in Australia. Accid Anal Prev. 2008;40(5):1750-1757.

28. Wilson JR, Norris BJ. Rail human factors: past, present and future" en Applied Ergonomics. 2005;36(25):649-660.

29. Schvarzer J, Gomez T. La primera gran empresa de los argentinos. El Ferrocarril del Oeste, Buenos Aires: Fondo de Cultura Económica. 2006.

30. Lopez M, Waddell J. Nueva historia del ferrocarril en la Argentina. Buenos Aires: Ediciones Lumiere. 2007.

31. Azpiazu D, Basualdo E. Las privatizaciones en la Argentina. Génesis, desarrollo y principales impactos estructurales. In: Petras J, Veltmeyer $\mathrm{H}$, editors. Las privatizaciones y la desnacionalización de América Latina. Buenos Aires: Ediciones Prometeo. 2004.

32. Schvarzer J. Los ferrocarriles de carga en la Argentina. Documento de trabajo No2, Centro de Estudios Económicos de la Empresa y el Desarrollo, FCE, UBA. 1999.

33. Rey Valderrama F. Comparaciones técnicas entre los anchos de trocha ferroviaria, yarda y estándar a propósito del proyecto del tren de cercanías. Ciencia e Ingeniería Neogranadina, julio. 2002;(12):6580.

34. Rozemberg A. Temas de explotación ferroviaria. Buenos Aires: Editorial Dunken. 2010.

35. Napoli I. Signos asociados al Trastorno por Estrés Postraumático en maquinistas de trenes del Área Metropolitana de Buenos Aires que participan en accidentes de arrollamientos de personas o vehículos, Buenos Aires: Superintendencia de Riesgos del Trabajo, Ministerio de Trabajo, Empleo y Seguridad Social de la Nación. 2006. 
36. Kholer M, Martin E. Verdugos inocentes. Estrés postraumático en conductores de trenes. Buenos Aires: Ediciones Oeste. 2009.

37. Law J. Ladbroke Grove, Or How to Think about Failing Systems', published by the Centre for Science Studies, Lancaster University, Lancaster. 2003.

38. Barton M, Sutcliffe K. Overcoming dysfunctional momentum: organizational safety as a social achievement. Human Relations. 2009;62(9):1327-1356

39. Weick K. Sensemaking in organizations. California: Sage Publications. 1995.

40. Department Of Civil And Enviromental Enginering Del Imperio College London. Fatal train accidents on britain's main line railways: end of 2009 analysis. London: Imperial College London. 2010.

41. Gilbert C. Erreurs, défaillances, vulnérabilités: vers de nouvelles conceptions de la sécurite? In: Borraz O, Gilbert C, Joly P. Risques, crises et incertitudes: pour une analyse critique. Grenoble: Publications de la MSH- Alpes. 2005.

42. Dejours C. El Factor Humano. Buenos Aires: Lumen Humanitas. 1998.

43. Dejours C. Trabajo y desgaste mental: una contribución a la psicopatología del trabajo. Buenos Aires: Lumen Humanitas. 2001.

44. Dejours C. Trabajo y sufrimiento. Madrid: Editorial Modus Laborandi. 2009

45. Vaughan D. The challenger launch decision. USA: The University of Chicago Press; 1996.

46. De La Garza C. Aportes del método de los puntos pivote a un estudio prospectivo de seguridad en el campo de la interoperabilidad ferroviaria. Laboreal. 2005;1(1):16-25.
47. De La Garza C, Weill-Fassina A. Aportes del trabajo colectivo a la gestión de la seguridad laboral en situación de riesgo en el ámbito ferroviario. Laboreal. 2006;2(2):38-46.

48. Roth E, Multer J, Rraslear T. Shared Situation Awareness as a Contributor to High Reliability Performance in Railroad Operations. Organization Studies. 2006;27(7):967-987.

49. Amalberti R. La conduite de systèmes à risques. Paris: Presses Universitaires de France. Collection Le travail humain. 1996.

50. Theorell T, Leymann H, Jodko M, et al. Person under Train" Incidents: Medical Consequences for Subway Drivers. Psychosomatic Medicine. 1992;54:480-488.

51. Nena E, Tsara V, Steiropoulos P, et al. Sleep-disordered breathing and quality of life of railway drivers in Greece. Chest Journal. 2008;134(1):79-86.

52. Cantero J, Gonzalez N. De la naturaleza y especificidad del sistema ferroviario argentino: el desafío de la confiabilidad. Revista Ciencias Administrativas. 2015;3(6):1-14.

53. Cantero J. La gouvernance de la gestion des risques industriels : entre la sécurité et la performance économique. Le cas des plateformes chimiques rhône-alpines. Tesis de Doctorado. IAE - Université Jean Moulin Lyon 3. 2007.

54. Gonzalez N. Paradojas del sistema ferroviario argentino. Reflexiones en torno a la confiabilidad y la vulnerabilidad en una línea metropolitana", Revista del Centro de Estudios de Sociología del trabajo. 2014;6 (2014):111-136.

55. Perrow $\mathrm{CH}$. Organizing to reduce the vulnerabilities of complexities. Journal of contingencies and crisis management. 1999b;7(3):150 155 .

56. Bourrier Mathilde. Organiser la fiabilité. Paris : L’Harmattan. 2001. 